\title{
CHRISTIAN EDUCATION OF THE RULER IN THE VISIGOTHIC KINGDOM
}

\author{
Maksym Saibekov \\ Department of General Pedagogics and Andragogy \\ Poltava V. G. Korolenko National Pedagogical University \\ 2 Ostrohradskyi str., Poltava, Ukraine, 36003 \\ maksimsaybekow@gmail.com
}

\begin{abstract}
The article is devoted to the educational model of the outstanding European thinker of the $7^{\text {th }}$ century, Isidore of Seville, with the principles of the education of the ruler and the class approach to the problem of teaching, with the content of the renovation pedagogy of the episcopal Gispal school of the VI-VIII centuries, its place in the evolution of the formation of Western European education. The article is dedicated to the problem of knowledge reception and work with the textbook during the «Dark Ages» in Visigothic Kingdom. An attempt is made to illustrate the process of reading through the reflection of this process in the creative heritage of Isidore of Seville (VII century). Therefore, our article is devoted to Visigoth Spain in VI-VII centuries, namely the formation of political, legal, moral and value concepts. Especially we pay attention to the image of the ideal ruler in the works of Isidore of Seville, Braulio of Zaragoza. We are trying to determine who should be the ideal ruler, and it is important to political and legal representation of the Visigoths, at a time when their culture reached its climax, absorbing the ancient traditions and world views. Isidor of Seville developed his own system of science independent learning for students, which has not lost its relevance today: a material, given by a tutor for independent learning, must be checked by parts, then each of these parts are translated out loud, and then the most important material was being selected from each part and as a result it is compiled into a student's report. Therefore, the place that Isidor occupies in the culture of his time is a key in the combination of two eras, and his educational program is thoroughly disclosed based on his main "pedagogical" texts.
\end{abstract}

Keywords: promotion, service quality, returning interest, tourists.

DOI: $10.21303 / 2504-5571.2020 .001209$

\section{Introduction}

Western Europe is grateful to those who stood at the origins of the Middle Ages, people, who have put together two cultural epochs, antiquity and the Middle Ages. The creative heritage of Isidore of Seville and Braulio of Zaragoza was completed and summarized in a stage of transition from Late Antiquity to the Early Middle Ages, showing us a special form of new man's thinking of the new epoch. So, perhaps we should not focus on the disappearance of ancient culture in this period, and should explore new theoretical and philosophical foundations of early medieval science and new pedagogical model [1].

In the preamble, Isidore explained the content of his work: "Etymology is the origin of words, when the essence of a word or a name is revealed through explanation". It was the etymological approach, first applied in "Differentiation", that allowed Isidore to seek out the foundations of being, because he proceeded from the deep interconnection of the word and what it means. Terminological research allowed the use of the mind in the process of knowing the truth. In "Etymology" it is stated, that concepts are not created and do not arise, but only exist and open in the word.

The works of G. Pikov and V. Bezgorov are devoted to the origins of the European model of education with its peculiarities of mentor behaviour [2,3]. The content of pedagogy in the era of the early Middle Ages and the role of the unique teacher in it has become the subject of the research by V. Ukolova and L. Kharitonov. Scientists proved that the university model in the Western Europe countries appeared in the $7^{\text {th }}-8^{\text {th }}$ centuries. However, due to objective external factors, it was possible to establish it only in the middle of the 11th century [4].

According to V. Ukolova, "the development of Isidorian historiography ranged from panegyric to hypercriticism" [5]. Due to the peculiarity of Isidore's creative method - compiling his own works as a "mosaic" of quotes - researchers did not consider him an original thinker for a long time and viewed his works as a "library", which contains traces of unsaved ancient texts. So, G. Becker in 1887 put forward the theory of influence of the lost collection of Suetonius "Meadows" 
(Prata) on Isidore's works [6]. Such attempts were finally rejected after the publication of the article "Isidore and Suetonius" by P. Wessner in 1917. Around the same time, attempts were made to determine the level of knowledge in the Dark Ages on the basis of the writings of Isidore, that is, in the quotes they saw primarily borrowings. The hypercritical approach, especially the characteristic of German and Anglo-American scholars, finally triumphed in a 1936 article by F. Seyvold Lear, which directly asked the question: "To what extent was Isidore a fool?" [5]. Such views were gradually eliminated in the post-war era, and in the period 1959-1960 an important milestone in Isidorian research was the publication of a two-volume monograph by J. Fontaine and a symposium in honor of the 1400th anniversary of Isidore of Seville. In these works, questions were raised about the originality of Isidore and the methods of working with his texts [7]. Fontaine's monograph reconstructed the composition of Isidore's knowledge in the disciplines of quadrivium, medicine, law and, in part, philosophy. In 1985, J. Hilgart's bibliography was published, in which all the main works on Isidore in European languages, published in 1936-1975, were summarized and annotated [8].

Almost all the authors, who wrote about Isidore and analyzed his sources, came to the conclusion that his erudition was fragmentary and he had a superficial reception of the philosophical heritage of antiquity. J. Fontaine wrote about this (based on the first three books of Etymologies), but he noted that Isidore considered secular knowledge, independent of Revelation. In 1982, a monograph was published by the Spanish researcher F. Lozano-Sebastian, who argued for the indirect influence of stoicism and Platonism on Isidore. New works began to appear in the 21st century, in connection with new editions and translations of the works of Isidore [9].

The purpose of the study is reproduction of the educational model of the Gispal School in the epoch of the episcopate of Sidor of Seville.

\section{Materials and Method}

One of the sources to which we turn, it is Braulio's letters - bishop of the Spanish city of Zaragoza from 631 to 651 . The letters reflect the image of the ideal ruler. One of the main qualities of exemplary monarch is justice. This term means firstly, that the king must obey the will of God, and secondly, it is the law. These foundational provisions were contained in the works of Isidore of Seville, especially in "Etymologies" [4].

The image of the ideal ruler was formed in Roman law and in the biblical tradition; in the works of Isidore they both complement each other. Obviously, the question of justice and legality in general become particularly acute when it comes to the relationship between the state and citizens. Hence a lot of interpretations of concepts were presented in the ancient and medieval texts [10].

As we know, the Visigothic monarchy was elected in VII century, resulting in a constant struggle for power. King Chindasuinth came to the throne as a result of a coup d'etat, when he was 79 years old. After the coronation, to avoid unrest, he executed many members of noble knights and their property was confiscated. At the same time the king went down in history as an active legislator - "Visigothic Julian". In addition, he started to work on the codification of laws, completed by his son Recceswinth (649-672) [11].

In those political conditions the ruler had to balance between the various factions of magnates, who claimed the throne. For the sake of peace and stability in the country, he must take care of legitimacy, and thus prove their right to do it. Following the adoption of Orthodox Christianity, Reccared (589) attracted Spanish-Roman episcopate, which was actively involved in this process, to solve this problem. Complex rituals developed a system of symbols of royal power, gave its sanctity and integrity and image of the ideal ruler, formed in the works of writers of the Church, also the Church and royal legislation were intended to strengthen the power of the monarch [5].

Isidore was a man of his time. Despite his comprehensive education, the son of a Gothic princess and belonged to notable Hispano-Roman families of high social rank, he stood on the positions of religious and social status education [12].

Considering man as a miniature copy of the Universe, Isidore inspiringly wrote: "The head of man is directed to heaven, and on it are two eyes, similar to the sun and moon. The breath of a person is like air, because it is precisely that it generates breath and exhale, similar to the numerous winds of the Earth The belly of a person can be compared to the sea, because all the liquids are gathered in it, 
as all the waters flow into the sea. Finally, the feet can be compared to the ground, because they are dry and contain as much heat as the earth. This mind is contained in the head of man and rises above the body as God is in heaven, He can inspect and control all things from a height" [4].

Man is endowed with bodily sensations, imagination and intelligence. "It is not good deeds, not carnal perception, but only by the mind we differ from the animals", Isidor says (Saint Gregory the Great, 2006, p. 157). He was finding the names which corresponding to Latin ones that were used as synonyms - Intelectus, Ratio, Inteligentia [13, 14].

Isidore of Seville clearly revealed the concept of "justice" in the "Etymologie", rightly stated that the ruler must respect the law. Isidore insisted on law-abiding rulers: “...only by example, they can force the subjects to obey the law, while in another case, the state risks falling into anarchy". As for the term iustitia, then it means justice in general [15].

With regard to the duties of the ideal ruler, the topic was developed in the treatises of Isidore of Seville. He consistently supported the idea that the emperor should ensure the prosperity of his subjects. Actually, it makes it fair. King performs its task by issuing laws that serve the public good. Ruler obeys the laws and oversees their implementation by himself [16].

Isidore developed a special theory for the education of the ruler. This idea keeps/takes a leading place in his third book "Sentences". According to the scientist, there might be different rulers - "evil" or "kind" - it all depends on the educator. And it is important not only to teach the king to speak eloquently, we must teach the sovereign to act correctly. If he is a good king, then he must first of all be the defender of his people, the faith, the father of all the poor, the chairman of all subjects in the country. The king must concentrate all power in his hands, and king's subjects of all categories must be responsible to the king for the power, conferred on them, which are constantly controlled by the king. If the slightest disobedience of subjects is not condemned, then this is not a worthy ruler, he gives only a bad example to his entourage [17].

As noted the Bishop of Seville, the king must always remember that his power comes from God, but that does not mean it is right to self-will. Instead of the burden of supreme power obliged him to take care of people. Using this power for the good of him, King performs his duty to God [18].

The most ancient thinkers like Seneca, Pliny the Younger and Dion Chrysostom agreed on one thing: the mission of the ruler is to serve the public good. Public good is inextricably linked with notions of equity and justice, as they insist on the rule of law. This idea was further developed in the works of Isidore. (Namely, scilicet or videlicet) That is, we can take up the position that the Roman ideal of a just and wise ruler was one of the sources for Isidore of Seville [19].

Thus, fairness was the mandatory quality of the ideal ruler. The notion «justice» means obedience to God's will and law-abiding. Roman and biblical traditions complement each other, fair law - it is nothing else as a royal instrument to establish the divine order on the land [20].

Assignment of the ruler was to establish law and order on the ground, it means to ensure the welfare of his subjects. For this the King must set up fair (equitable) laws and obey them as law-abiding and it is the second meaning of the notion "justice". This is due to the obligation to do what he must - the third value [21].

It is essential to the relationship of power and the Church, Isidor sharply disagreed with Pope Gregory the Great. We are not finding anywhere in Isidore's works the idea that ruler must depend on the Church (idea of Papocaesarism). On the contrary, the authority of the church in the society should be based only on its moral examples. Every other authority in the state is the power of the king, Isidore believed [22].

So, familiarized with the invaluable cultural and legal heritage of «cultural barbarians» the Visigoths, we can not only trace the influence of ancient heritage to legal viewpoint of the Visigoths, but also analyze their desire to have a fair-minded ruler [13].

Today it is a very current question of the ideal ruler, but as we have noted above, the power is not only a means to realize own ambitions, it is also a great duty and responsibility, because, firstly, the ruler must answer to his own conscience and dignity, and secondly, be responsible to the society that trusted him [23].

Among the intellectual elite of that time there was an important state task - education - since it was directly related to the education and upbringing of the younger generation, it was not enough 
to take its place in the society. A distinctive feature of the western half of the empire, determined for many centuries the fate of Western Europe, where there was an almost complete absence of a bureaucratic state apparatus, which was preserved only in Byzantium. Accordingly, the task of supporting the corps again was not standing here. By the sixth century, a social system had already formed in Spain, which with some changes existed until the era of bourgeois revolutions: laborantes ("working") militantes ("those that fight") and oratores ("praying"); these were three completely different worlds with different ideas about life, qualities and laws. The "workers" made up the bulk of the peasant population and servants; they were mostly autochthonous (local people). "Those who fight" - this is the military power, which in those days did not differ from the executive power; it consisted mainly of a small hereditary aristocracy of foreign barbarians. "General education" in these conditions could not be considered. First of all, no one was going to train the "workers": their task was to work, and for this, to master the skills of agriculture and handicrafts. First of all, manifestations of military and administrative talents were also expected from the "warring": after all, even after centuries, most European knights, as well as often kings, remained illiterate. Although in fairness it is necessary to note that, in the ruling elite of the kingdom of Toledo, the situation was better, for example, King Sisebut made several dozen regular Latin hexameters about the lunar and solar eclipses. But the real education was given exactly to the "praying", and the second council in Toledo was already 531 [24]. He paid special attention to the education of the clergy. The children, who were appointed to the white clergy, were directed to the "church house" under the leadership of the bishop, and specifically their own without the right to transfer them to another bishop, so that "the bishop himself would not be able to be in gross ignorance and illiteracy". Since secular schools simply died along with the collapse of the administrative apparatus of the Roman Empire, the task of education completely shifted to churches and monasteries, that is, to cathedral and monastic schools. But the content of educational programs was borrowed from the educational literature of antiquity, that is, it was purely secular. Therefore, for the church, the Christianization and desecularization of the sciences was of paramount importance, and in general this task was accomplished by the middle of the 6th century, namely in the works of Cassiodorus [25].

First, Isidore continued the work of Martin Brakarsky and his brother to eradicate the Aryan heresy, and also reappearing sects, such as acephalus heresy. Here his efforts were crowned with the complete success. Religious discipline was strengthened, he himself chaired, as a confidant and adviser to the kings, whose political line he invariably supported and strengthened [26].

Secondly, he proposed to unite the people with the school system, for which an educational program was proposed and the schools themselves were consistently created. Presiding at the fourth council in Toledo, he issued a decree on the establishment of a Hispal-style school in all cathedral cities. It was prescribed to study not only Christian sciences, but secular free arts, even Greek and Hebrew languages. Interest in medicine and jurisprudence was also encouraged, which laid the medieval system of three university departments - theological (with a mandatory preliminary study of the arts), legal and medical. Even in the Arabs, he sought to maintain interest in Aristotle [27].

The entire school curriculum was presented in a huge compilation of works, called "Etymology, or Beginning in the XX books." Here, for the first time in philosophical practice after Posidonius, an encyclopedia (summa) of universal knowledge was created, interpreting everything that was studied both in antiquity and relatively recently. This work, of course, gives the right to call Isidore the most educated person of his time [4].

1. The principle of definition (etymology). The entire work is not without reason called "Etymology". Isidore was quite a normal thinker of his time, that is, he tried not to penetrate the secrets of the real, changing the world as much as he constructed his intelligible idea of the world with verbal means. He examines not the real beginnings of things, but the ideal beginnings of concepts. Where reality and concepts are adequate, he conveys this; in the same place, where a contradiction arises between reality and concept, preference is unconditionally given to the word. Such were the new Christian trends, which represented the visible world to man only as an instant in a higher divine reality. For example, Isidore does not distinguish between letters and sounds, they designate, he says "letter" in both cases, almost does not distinguish between nouns and objects, they designate, do not distinguish the verb from the actions themselves, what they express. In fairness 
it should be noted, that the attempt to seriously doubt that, in fact, things, as we say about them, was undertaken in antiquity. This is the famous Plato's "Cratylus". Therefore, ancient and medieval thinkers seriously believed that everything in the world is the way it is, as it is said in human language - among philosophers this is called the principle of "the identity of being and thinking", which refers to the thesis of Parmenides of Elea [15].

For Isidore, to find out is inherently to find the name in the endless list of things, since the word was perceived not as a greater or lesser adequate similarity of a thing in human thinking, but as a larger reality than this thing itself, or rather, the "current" thing was simply not considered a real reality. At the same time, he believed that scientific knowledge is not progressing, but degrading, which is associated with confusion, which is introduced into the meaning of various scientific terms by epigones. Therefore, the meaning of the concepts must be clarified and cleaned of the later layers. According to this methodological basis, he proceeds to research [28].

In general, one can say that all his "Etymologies" are a detailed structured explanatory dictionary, that is, they only consist of concepts and definitions. In the most complete cases, the answer to the question "what is it?" consists of four parts: definition through gender and species differences ("what is it?"), Etymology (“why is it so called?"), Classifications (“into which species is it divided?") and example.

Of course, the weakest link in this four-part definition is precisely etymology, since it is usually Greek, and Isidore did not know this language. It should be added to what Brecheit said on this point, that the dates in the manuscript are in Greek that, as a rule, tend to be correct. Isidore apparently knew the rules for using the most famous borrowed Greek words in Latin still from the school curriculum, so he was not mistaken in simple cases. In addition, he had a Roman-Greek dictionary or someone from the Seville scriptorium who could give him a Greek equivalent of the Latin term. But this knowledge of his Greek is limited, because in more complex cases, Isidore simply did not understand Greek mythology.

2. The principle of classification. It has an independent and noticeable value. As in the case of classification, and in the case of hierarchy, the essence boils down to the principle of visual presentation, formulated by Plato: "The business of a free person is to be able to visualize in his mind what he is talking and thinking about." In Isidore, unlike the Neo-Platonists, we have not so much a hierarchy as the good old classification indicates an early type of scientific thinking. This principle of visual representation itself goes back to the quite ordinary consciousness of the Hellene, to his "spectacle of consciousness", using the good term by A. V. Akhutin. A Hellene tried to think as he lived in his society: the theater and the court (for example, the Areopagus), gave him the opportunity to contemplate the essence of the matter visually and from the side [5].

Developing his theory of upbringing, Isidore of Sevill came to the conclusion that in order to have the right to become a tutor, it is necessary to go through several major stages: firstly, the preparatory stage for teaching (Doctrina) - creating your own system of transferring general knowledge, secondly, (Sapienta) - the attainment of wisdom in the process of teaching the basics of knowledge to individual students, who wish to study with an inexperienced teacher, and thirdly, (Prudentia) - the achievement of true piety by a teacher. Only after that he had the right to teach in the episcopal school or to be a teacher of children of nobles or kings [4].

The Isidorian theory of the education of the ruler that was outlined by him in "The instructions to the king Sisebut" and "Etymologiae" is extremely valuable for us. The power is given to the king by God, because he is elected, otherwise the ruler is just an ordinary person, who should be adequately educated. The secular ruler must have exceptional qualities. These include justice, piety, wisdom, patience, meekness, mercy. And yet the king's main business is the righteous act and the observance of justice. The following principles should be based on exclusive justice, equality of all before the law, impartiality. The word of the ruler should never be at variance with the action [29].

Thus, Isidore recommended Sisebut to act: "Prove what you say through your mouth, an example confirms what you learn in words. Be not only a mentor, but likewise you need to be inclined to charity. Only when you become famous, then you will always do that you teach others" [5].

Only when the king is being ideal, in that case, the subjects will feel respect for the authorities, thoroughness in the performance of their duties and love. However, unreasonable orders of 
the ruler should not be carried out. Here is how it sounds from Isidore's own words: "If you get an order to do evil, then do not put up with it. If you are ordered to do something horrible, do not obey. Whichever authority ordered it, do not ever agree to do evil, even if you will be severely punished, even if you are threatened with anguish and torture. To die is not so terrible as to carry out disastrous orders... He is not free from the crime, the one, who does it by someone else's order. He, who obeys evil, does not differ from one who does evil. The same punishment binds the one, who conceived, evil with the one, who allowed him. For God, there is no difference" [5].

Any educational system is historical, it is closely connected with the evolution of the society. A certain stage of development of the society, as a rule, corresponds to a certain system of education and upbringing. Every society has its own educational mechanism for generating new life forms.

The Middle Ages are associated in our consciousness primarily with its three institutions the Church, the Empire and the University. Of these, the first two came in the Middle Ages from antiquity, and only the university was born precisely by the Middle Ages. A striking feature of medieval culture is its written character. Instead of enlightened leisure, characteristic for antiquity ("scholii"), the work of a scientist appears ("pragmatism" is a practical ethical work, a treatise), instead of oral culture, it is written one. This makes it possible to transmit knowledge to other epochs. The cult of the word is claimed. Therefore, sermons and prayers are of such great importance in the Middle Ages. The text is of great importance. To attain the goal that the medieval man set for himself, namely, to comprehend God, it meant all his life to read and interpret the same text, that is, the Bible. He is subordinated to the educational purpose and nature. The whole world becomes a textbook, nature - a visual aid [30].

So, the fathers and teachers of the Church, in particular Isidore of Seville, Alcuin, St. Augustine, Thomas Aquinas, played an important role not only in preserving ancient knowledge, but also took an active part in shaping the content of education and the theory of education, namely "what to teach, how to teach and how to learn".

Therefore, the place that Isidor occupies in the culture of his time is a key in the combination of two eras, and his educational program is thoroughly disclosed, based on his main "pedagogical" texts.

The activity of Isidore as a pastor and teacher reflects the final stage of the patristic period (early Christianity), and consisted in completing the selection of the ancient cultural heritage and the systematization of selected information into the canon of church scholarship, which is reflected in his works, such as Etymology and Differences.

The practice of transferring knowledge and skills of their mastering is devoted to the chapters of his treatise "Sentences", where the leitmotif is the idea of the moral and theological significance of reading and learning. This explains why Isidore so carefully reacted to ancient culture, rejecting rhetoric, poetry and philosophy in his canon.

If Isidore practically succeeded in embodying the ideal of the ruler in his disciple Sisebute, then, observing the broad masses of the uneducated population of Visigothic Spain, at the end of his life he wrote the following: "People are mostly lazy towards science, inclined to bodily pleasures, indifferent to work. They are worried about petty worries, each person is mortal. In descendants they are not sure, they complain about a life that is fleeting, they are hard to get wisdom, but they are always easy to die. They are naked before the past, in front of present miserable, the future for them is unknown. They are in injustice, they are born by sinners, they live for working, they die in sadness" [5].

\section{Result}

Therefore, we observe that the educational system of Isidore of Seville within the society is delineated very clearly. By its nature it is Christian, in structure - vassal (seigneurial) and estate. Obviously, for Isidore, who in part worked in the fairly stable political situation in Visigothic Spain, this was an ideal way of maintaining order in the state.

The place that Isidore occupied in the culture of his time is shown, his attitude to education is revealed on the basis of his main "pedagogical" texts. The activity of Isidor as a pastor and teach- 
er reflects the final stage of the patristic period (early Christianity), and consists in the completion of the selection of the ancient cultural heritage and the systematization of selected information into the canon of ecclesiastical scholarship, as reflected in his works such as "Etymologies" and "Differences". The experience of using this knowledge and practice, mastering them, are devoted to the sections of his treatise "Judgments", where the idea of the moral and theological significance of reading and teaching is conducted. This explains why Isidore so carefully treated the ancient culture, throwing rhetoric, poetry and philosophy in his canon.

The conquest of the Iberian Peninsula by the Arabs interrupted the accelerated development of local education, but did not destroy the works of Isidore of Seville. Similar educational system arose in a century and a half in the Empire of Charlemagne, but the political instability of his (Charles's I) vast state had a negative impact on educational processes.

And only in the middle of the XI century, as a result of the relative stabilization of international relations and the impulse of an economic nature in medieval Europe, the rapid growth of cities began, which led to the formation of a new civilizational and, with it, a pedagogical paradigm.

The rising of urban culture led to the emergence of an intelligent person as one of the masters, whose craft was only "writing and teaching". Due to commercialization of the medieval society, the products of intelligence turned into a product that needed to be realized on the market of intellectual services. The educational model also changed. The tutor replaced the magister (magister, doctor - teacher, head of the learning process) - an intellectual, taught methods of thinking. Unlike the mentor in faith and study, who was Isidore, the master was already a narrow specialist (specialis - from latin, special, private), that is, an expert in only part of a certain narrow field of knowledge.

\section{Conclusions}

Thus, the origins of modern Western European tutoring (mentoring) are based on the pedagogy of mentoring in the early Middle Ages, when the teacher offered a model of the necessary amount of knowledge and a model of behavior in learning and society, self-learning of this model by a pupil under the supervision of a mentor, however without special coercion and authoritarian methods of upbringing. This problem is not fully covered by the works that exist at the present time, and requires a deeper research.

\section{References}

[1] Braulion of Zaragoza. Izbrannye pisma (2011). Moscow: SOIUZNIK, 64.

[2] Pikov, G. G. (2000). Renovacionnaia pedagogika Karolingskogo Vozrozhdeniia i pedagogicheskie idei Alkuina. Istoriia i sotsiologiia kultury. Istoriia i sotsiologiia obrazovaniia. Novosibirsk: NSU, 32-81.

[3] Bezrogov, V. G., Varyash, O. I. (1994). Pedagogika Srednevekovia. Antologiia pedagogicheskoi mysli khristianskogo Srednevekovia. Moscow: Eurasia, 11-28.

[4] Kharitonov, L. A. (2006). Isidor Sevilskii. Istoriko-filosofskaia drama v semi episodiiakh s prologom i eksodom. Moscow: Eurasia, 352.

[5] Ukolova, V. I. (1989). Antichnoe nasledie i kultura rannego Srednevekovia. Moscow: Nauka, 320.

[6] De natura rerum liber. Ed. G. Becker. B. (1857). (1985). Sotsial'no-politicheskoye razvitiye stran Pireneyskogo poluostrova pri feodalizme. Moscow, 136-153.

[7] Fontaine, J. (1959). Isidore de Séville et la culture classique dans l'Espagne wisigothique. Paris: Études augustiniennes, 1013.

[8] Hillgarth, J. N. (1983). The Position of Isidorian Studies: A Critical Review of the Literature: 1936-1975. Estratto dagli Studi Medievali, XXIV, II.

[9] Lozano, S. F. J. (1982) San Isidoro de Sevilla: Teología del pecado y la conversión. Burgos.

[10] Barney, S. A., Lewis, W. J., Beach, J. A., Berghof, O. (2006). The Etymologies of Isidore of Seville. Cambridge: Cambridge University Press. doi: http://doi.org/10.1017/cbo9780511482113

[11] Castro Caridad, E., Peña Fernández, F. (2012). Isidoro de Sevilla. Sobre la fe católica contra los judíos. Sevilla: Universidad de Sevilla, 188.

[12] Jones, P. (2006). Patron saint of the internet (Review of The Etymologies of Isidore of Seville). Cambridge University Press.

[13] Dillon, M. (1978). Early Irish literature. Chicago: Univ. Press.

[14] Dodsleu, R. A. (1998). Select a collection of old English plays. Strassburg: Black. 
[15] Isidore of Seville. Etimologii, ili Nachala (2006). Saint Petersburg: Eurasia, 352.

[16] Volkov, A. A. (2016). Bishop Isidore of Seville and his treatise De ecclesiasticis officiis as a source of information about the liturgical tradition of the Ancient Church. Khristianskoe chtenie, 4, 139-153.

[17] Vorontsov, S. A. (2015) Isidor Sevil'skiy v istoriko-filosofskom kontekste. Moscow: MGU im. M. V. Lomonosova, 230.

[18] Fokin, A. R. (2011). Isidor Sevilskii. Pravoslavnaia entsiklopediia. Moscow: The Church and Science Center "Pravoslavnaia enciklopediia", 224-238.

[19] Krinitsyina, E. S. (2011). Predstavleniia o sude i pravosudii v Toledskom korolevstve VII veka. Iuridicheskie zapiski, 24 (1), 32-38.

[20] Marshall, P. K.; Marshall, P. K. (Ed.) (1983). Introduction. Isidorus Hispalensis. Etymologiae II. Rhetoric. Paris: Les belles lettres, 183.

[21] Throop, P. (2005). Isidore of Seville's Etymologies. Charlotte: MedievalMS, 2 vols.

[22] Saint Gregory the Great. Pastyrskoe pravilo. Moralnye besedy, na knigu Iova (2006). Moscow: Eurasia, 306.

[23] Throop, P. (2012). Isidore's Synonyms and Differences. (a translation of Synonyms or Lamentations of a Sinful Soul, Book of Differences I, and Book of Differences II). Charlotte: MedievalMS, 262.

[24] Vestgotskaia pravda (1999). Available at: http://www.vostlit.info/Texts/Dokumenty/Spain/VII/Westgot_recht/text1.htm

[25] Brehaut, E. (1912). An encyclopedist of the Dark Ages: Isidore of Seville. New York: Columbia University, Longmans, Green \& Co., agents; L.: P. S. King \& Son, 274.

[26] Ziolkowski, V. P. (1982). The De Fide Catholica contra Iudaeos of Saint Isidorus, Bishop, Book 1. Saint Louis University.

[27] Shachtman, N. (2002). Searchin' for the Surfer's Saint. Available at: https://www.wired.com/2002/01/searchin-for-the-surferssaint/

[28] Herren, M.; James, E. (Ed.) (1980). On the Earliest Irish Acquaintance with Isidore of Seville. Visigothic Spain: New Approaches. Oxford: Oxford University Press, 243-250.

[29] Henderson, J. (2007). The Medieval World of Isidore of Seville: Truth from Words. Cambridge: Cambridge University Press, 232.

[30] Englisch, B. (1994). Die Artes liberales im frühen Mittelalter. Stuttgart, 494.

Received date 07.02.2020

Accepted date 24.03.2020

Published date 31.03.2020
(C) The Author(s) 2019

This is an open access article under the CC BY license (http://creativecommons.org/licenses/by/4.0). 